\title{
Patterns of Habitation and Burial Activity in the Ban Rai Rock Shelter, Northwestern Thailand
}

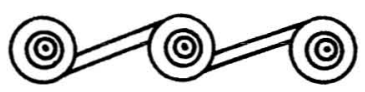

\author{
CHERDSAK TREERAYAPIWAT
}

THE EXCAVATION OF THE BAN RAI ROCK SHELTER reported here is part of the Highland Archaeology Project, which is investigating cultural chronology and palaeoenvironment in the district of Pang Mapha in northwestern Thailand (Shoocongdej 2000, 2001, 2002a, 2002b). The site had been surveyed and studied by a number of researchers previously (Fine Arts Department 1987; Krajaechan 2001; Sawatsalee 1998; Treerayapiwat 1998), but not excavated. These surveys noted a wide diversity of archaeological evidence including log coffins, stone tools, sherds of pottery, animal bones, and rock paintings. The log coffins, which were used in human burial practices, were dated to ca. 2100-1200 B.P. (ca. 100 B.C.-A.D. 800) (Grave 1995) and can be associated with similar burial practices throughout Southeast Asia (Cheng 1969; Harrisson and Harrisson 1971; Tenazas 1983). The surface evidence at Ban Rai is also very similar to the evidence recovered from Spirit Cave, the first archaeological excavations carried out in Pang Mapha district (Gorman 1970). These excavations indicated that the earliest evidence of habitation was about 12,000 B.P. Gorman defined two cultural periods in the cave sequence, which he labeled the upper and lower Hoabinhian. Carbonized grain in the lower layers was taken as evidence of early agriculture, with cord-marked pottery and ground-stone tools appearing in the upper layers (Gorman 1971; Higham 1977). Although Gorman also found evidence for later Log Coffin burials (which are commonly found in caves in the region), he did not discuss them in any detail. Hence a goal of the Ban Rai excavation was to attempt to provide a detailed cultural chronology of Log Coffin burials in addition to any other evidence for settlement. This paper is, therefore, a preliminary report relating to the excavated cultural layers from the Ban Rai rock shelter, which has proved to have significant evidence relating to changing human activities and usage of the site.

\section{THE EXCAVATIONS}

Ban Rai is located at approximately latitude $19^{\circ} 31^{\prime} \mathrm{N}$ and longitude $98^{\circ} 31^{\prime} \mathrm{E}$, at ca. 740-760 $\mathrm{m}$ above sea level, perched on the southern edge of a steep-sided 


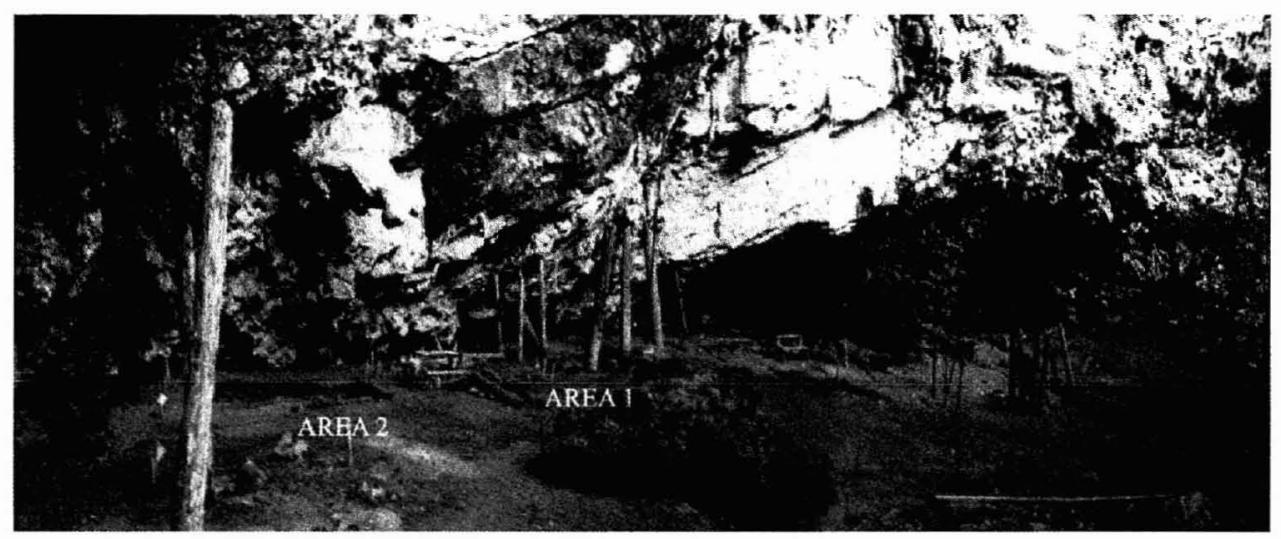

Fig. 1. View of Ban Rai rock shelter, showing the location of the excavated Areas 1 and 2. (Photograph: Pipad Krajaechan)

river valley about $2-3 \mathrm{~km}$ to the west of the nearest village of Ban Huai Rai (Ban Hai). ${ }^{1}$ The Lang River, at the base of the valley, about $200 \mathrm{~m}$ below the site, flows from the east to drain into a sinkhole located just to the west of the site. Ban Rai is one of many large caves and sinkholes located in the karst landscape of this region. The rock shelter measures ca. $105 \times 42 \mathrm{~m}$, closely resembling a circular sinkhole in shape. There are many rock falls on the surface of the site, and especially on the western side. The floor of the shelter is uneven along the base of the cliff, although the most significant topographic feature of the site is the general slope away from the sheltered dry areas down toward the unprotected central area (Figs. 1 and 2).

The excavation was preceded by the creation of a $5 \times 5 \mathrm{~m}$ grid system over the entire site. Three areas were then selected for excavation within this grid (Fig. 2). Area $1(14 \times 2 \mathrm{~m})$ was chosen because it lay between a pair of large wooden posts from the Log Coffin period, as well as another smaller coffin closer to the rock wall. The trench covered an area that sloped away toward the center and western side of the site. The quantity of soil excavated was about $57.4 \mathrm{~m}^{3}$. Area 2 , about 5 $\mathrm{m}$ to the east of Area 1, was selected for excavation because it covered the highest mound in the site and its surface contained lithic as well as Log Coffin artifacts. The trench measured $4 \times 4 \mathrm{~m}$, and was later extended by $2 \times 4 \mathrm{~m}$ to the wall of the rock shelter; about $37.8 \mathrm{~m}^{3}$ of soil was excavated. Area 3 was situated on the eastern side of the rock shelter, in an area that also contained both lithic and Log Coffin artifacts. This trench also measured $4 \times 4 \mathrm{~m}$, but was again extended up to the edge of the rock wall; about $44.8 \mathrm{~m}^{3}$ of soil was removed. Excavation was carried out using a series of $10 \mathrm{~cm}$ spits measured down from a fixed datum point, but wherever possible we followed significant features and natural layers of sedimentation. Area 3 contained the largest number of finds (in relation to the quantity of soil removed), with Areas 1 and 2 producing smaller assemblages of similar size.

A series of prehistoric rock paintings was located close to Area 3 on the eastern edge of the site, with the largest and most detailed painting located about $10 \mathrm{~m}$ to the south of the trench (Fig. 2). The paintings depict both realistic and idealistic 


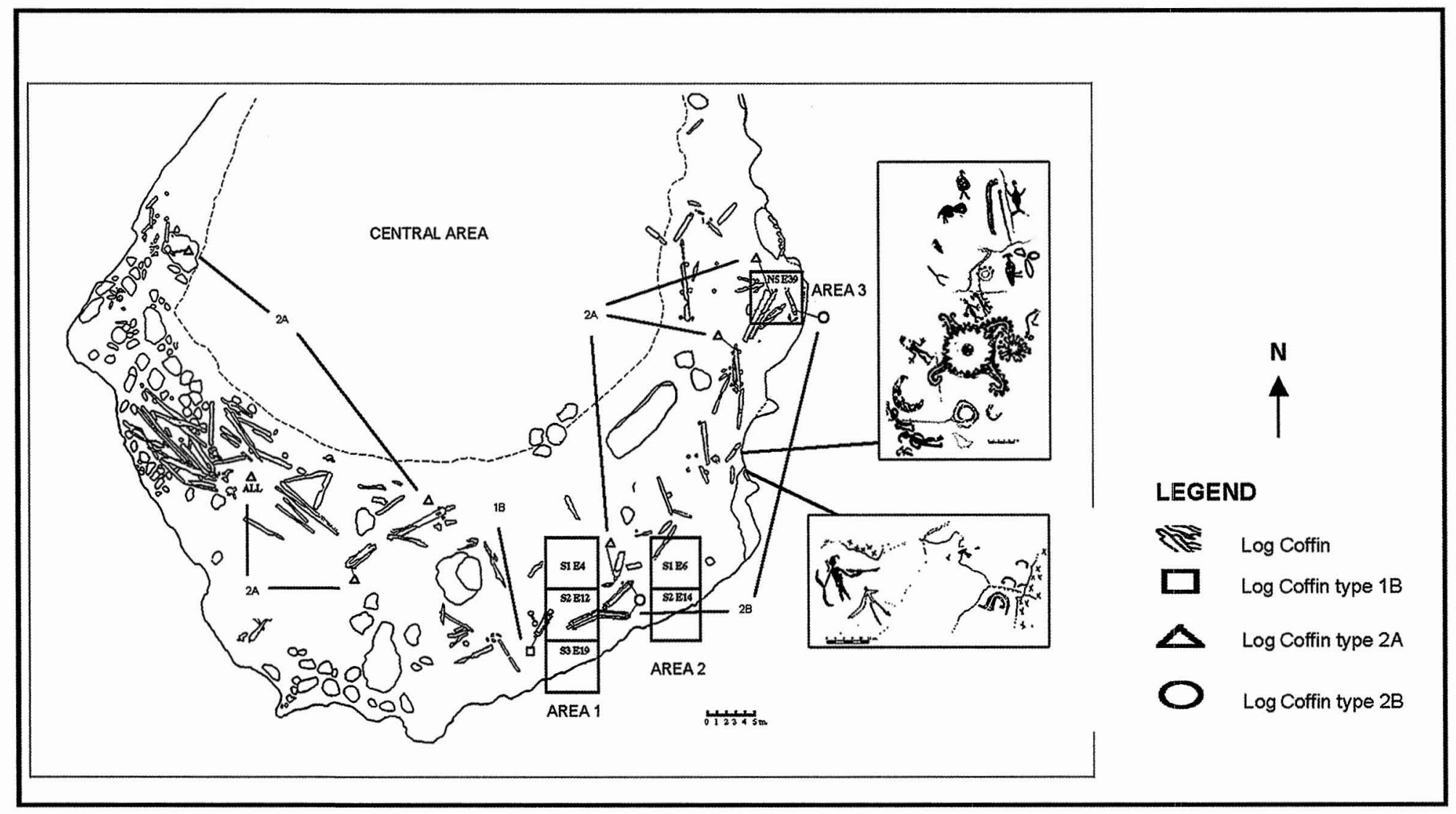

Fig. 2. Plan of Ban Rai rock shelter, showing the location of the excavations, rock paintings, and coffins, along with their designated types. 
Table i. Ban Rai: The Quantity of Artifacts Recovered from the Stratigraphic Layers in Area i. The Total Quantity of Artifacts does not Include those Artifacts Recovered from within Features or Heavily Disturbed Areas. See Table 4 for ${ }^{\text {I4 C Details. }}$

\begin{tabular}{|c|c|c|c|c|c|c|c|c|c|}
\hline COMPONENT & PERIOD & $\begin{array}{c}\text { STRATIGRAPHIC } \\
\text { LAYER }\end{array}$ & LITHICS & $\begin{array}{l}\text { ANIMAL } \\
\text { BONE }\end{array}$ & SHELLFISH & $\begin{array}{l}\text { POTTERY } \\
\text { SHERDS }\end{array}$ & $\begin{array}{l}\text { IRON } \\
\text { TOOLS }\end{array}$ & $\begin{array}{l}\text { HUMAN } \\
\text { BONE }\end{array}$ & ${ }^{14} \mathrm{C}$ DATING \\
\hline \multirow{8}{*}{$\begin{array}{l}2 \\
\text { Log Coffin culture } \\
1 \\
\text { Pre-Log Coffin culture }\end{array}$} & Late Holocene & 1 & 132 & 1,029 & 54 & 2131 & 2 & 29 & - \\
\hline & $\begin{array}{l}\text { Early Holocene to } \\
\text { late Pleistocene }\end{array}$ & 2 & 429 & 7,234 & 349 & - & - & - & $9400 \pm 120$ в.P. \\
\hline & & 3 & 146 & 10,015 & 409 & - & - & - & - \\
\hline & & 4 & 50 & 1,196 & 82 & - & - & - & $10,600 \pm 40$ в.р. \\
\hline & & 5 & - & - & - & - & - & - & - \\
\hline & & 6 & - & - & - & - & - & - & - \\
\hline & & 7 & - & - & - & - & - & - & - \\
\hline & & 8 & - & - & - & - & - & - & - \\
\hline
\end{tabular}


Table 2. Ban Rai: The Quantity of Artifacts Recovered from the Stratigraphic Layers in Area 2. The Total Quantity of Artifacts does not Include those Artifacts Recovered from within Features or Heavily Disturbed Areas. See Table 4 for ${ }^{\mathrm{I}} \mathrm{C}$ Details.

\begin{tabular}{|c|c|c|c|c|c|c|c|c|c|}
\hline COMPONENT & PERIOD & $\begin{array}{l}\text { STRATIGRAPHIC } \\
\text { LAYER }\end{array}$ & LITHICS & $\begin{array}{l}\text { ANIMAL } \\
\text { BONE }\end{array}$ & SHELLFISH & $\begin{array}{c}\text { POTTERY } \\
\text { SHERDS }\end{array}$ & $\begin{array}{l}\text { IRON } \\
\text { TOOLS }\end{array}$ & $\begin{array}{c}\text { HUMAN } \\
\text { BONE }\end{array}$ & ${ }^{14} \mathrm{C}$ DATING \\
\hline \multirow{5}{*}{$\begin{array}{l}2 \\
\text { Log Coffin Culture } \\
1 \\
\text { Pre-Log Coffin Culture }\end{array}$} & Late Holocene & 1 & 157 & 1753 & 102 & 260 & 1 & 8 & - \\
\hline & $\begin{array}{l}\text { Early Holocene to } \\
\text { late Pleistocene }\end{array}$ & 2 & 146 & 2,228 & 81 & - & - & - & - \\
\hline & & 3 & 140 & 281 & 31 & - & - & - & - \\
\hline & & 4 & 479 & 10,172 & 502 & - & - & - & $\begin{array}{r}9410 \pm 80 \text { в.P. } \\
10,210 \pm 50 \text { в.P. }\end{array}$ \\
\hline & & 5 & - & - & - & - & - & - & - \\
\hline
\end{tabular}


Table 3. Ban Rai: The Quantity of Artifacts Recovered from the Stratigraphic Layers in Area 3. The Total Quantity of Artifacts does not Include those Artifacts Recovered from within Features or Heavily Disturbed Areas. See Table 4 for ${ }^{14} \mathrm{C}$ Details.

\begin{tabular}{|c|c|c|c|c|c|c|c|c|c|}
\hline COMPONENT & PERIOD & $\begin{array}{c}\text { STRATIGRAPHIC } \\
\text { LAYER }\end{array}$ & LITHICS & ANIMAL BONE & SHELLFISH & $\begin{array}{l}\text { POTTERY } \\
\text { SHERDS }\end{array}$ & $\begin{array}{l}\text { IRON } \\
\text { TOOLS }\end{array}$ & $\begin{array}{l}\text { HUMAN } \\
\text { BONE }\end{array}$ & ${ }^{14} \mathrm{C}$ DATING \\
\hline \multirow{7}{*}{$\begin{array}{l}2 \\
\text { Log Coffin Culture } \\
1 \\
\text { Pre-Log Coffin Culture }\end{array}$} & Late Holocene & 1 & 474 & 368 & 13 & 216 & 1 & 6 & - \\
\hline & $\begin{array}{l}\text { Early Holocene to } \\
\text { late Pleistocene }\end{array}$ & 2 & 1,151 & . 1,699 & 54 & - & - & - & - \\
\hline & & 3 & 4,439 & 10,845 & 637 & - & - & - & $7250 \pm 40$ в.Р. \\
\hline & & 4 & 392 & 598 & 138 & - & - & - & - \\
\hline & & 5 & 3,186 & 5,400 & 529 & - & - & - & $\begin{array}{l}8190 \pm 50 \text { в.Р. } \\
8850 \pm 50 \text { в.P. }\end{array}$ \\
\hline & & 6 & 8 & 1,366 & 21 & - & - & - & \\
\hline & & 7 & - & - & - & - & - & - & - \\
\hline
\end{tabular}


images, including a large scene that contains human figures, several drawings of animals, and a number of other symbolic images. The human figures appear to be in the process of a movement or action, possibly dancing, and are situated, along with a number of different animal figures, around one large circular image. Another painting, located on the roof of a small crevice below the largest painting, depicts a human figure that appears to be carrying a bow. A principal theme of the paintings appears to be relations between humans and their landscape (Sawatsalee 1998). It is worth noting here that the Area 3 excavation uncovered a piece of limestone measuring $10.2 \times 11.1 \times 4.4 \mathrm{~cm}$ and roughly in the shape of a crucible, with a distinctive red circle in the center; it is possible that this artifact was used as a container or mixing bowl for paint.

In each area, potsherds and iron tools were found only within the first few excavated levels, though lithic artifacts (including sumatraliths, short axes, waisted cores and flakes, and utilized cores and flakes), animal bones, and shellfish continued throughout the excavated levels (Tables 1-3). The potsherds are similar in type and cord-marked design to those recovered from similar Log Coffin sites across Pang Mapha (Hoontrakul et al. 2002; Shoocongdej 2000). The presence of potsherds and iron tools is regarded as a significant cultural indicator, allowing the definition of two separate cultural components at the site: the preLog Coffin culture, where the artifact assemblage contains an abundance of lithic tools and animal or shellfish remains; and the Log Coffin culture, where the artifact assemblage includes the presence of potsherds and iron tools.

\section{THE PRE-LOG COFFIN CULTURE}

Based upon the evidence of the archaeological stratigraphy, several ${ }^{14} \mathrm{C}$ dates (Table 4), and the artifact assemblages, the first component at Ban Rai, the PreLog Coffin culture, can be identified as falling within the late Pleistocene to early Holocene period. The earliest cultural layers were uncovered in Area 1, and can be dated to ca. $12,500-10,250$ B.P. This is very similar to the dates assigned to the earliest cultural layers in Area 2, but earlier than the dates recovered from Area 3. The lithic assemblage represented the entire spectrum of production, repair, and use, with the inclusion of utilized cores and flakes, wasted cores and flakes, hammers, and resharpening flakes. Animal and shellfish remains were also recovered in abundance. The majority of the material was found within ash-rich layers, an association particularly evident within Layer 3. Layers 2 and 3 clearly display an increase in the density of evidence they contain (Table 1).

Area 2 produced a similar artifact assemblage including a range of lithic and faunal evidence. Again, the majority of artifacts were found within ash layers, though the latter were often far less disturbed than in Area 1, making it possible to distinguish a number of fire locations or hearths, especially in Layer 4. Most significantly, though, Area 2 also produced a burial pit, roughly circular in shape and ca. $30 \mathrm{~cm}$ deep, containing a primary flexed burial (Fig. 3). Although the skeleton was extremely fragile and its detailed examination is still in progress, preliminary analyses of the skull and innominate bones has identified the body as a male. A charcoal sample taken from near the left humerus of the skeleton has been dated to ca. 9800 B.P.

A similar artifact assemblage was also recovered from Area 3, including a large 
Table 4. Radiocarbon $\left({ }^{14} \mathrm{C}\right)$ Dates from Ban Rai Rock Shelter

\begin{tabular}{|c|c|c|c|c|c|c|c|}
\hline SAMPLE DATA & AREA & LEVEL & LAYER & $\begin{array}{c}\text { ARCHAEOLOGICAL } \\
\text { CONTEXT }\end{array}$ & $\begin{array}{c}\text { MEASURED } \\
\text { RADIOCARBON AGE }\end{array}$ & ${ }^{13} \mathrm{C} /{ }^{12} \mathrm{C}$ ratio & $\begin{array}{l}\text { CONVENTIONAL } \\
\text { RADIOCARBON AGE }\end{array}$ \\
\hline $\begin{array}{l}\text { Beta-168215 } \\
\text { Sample: MHSBRAR 1-073 } \\
\text { Analysis: Radiometric-Standard } \\
\quad \text { delivery (with extended counting) } \\
\text { Material: Charred material }\end{array}$ & 1 & 4 & 2 & $\begin{array}{l}\text { Hearth and ash mixed } \\
\text { with many flakes }\end{array}$ & $9400 \pm 120$ в.Р. & $-25.0 * 0 / 00$ & $9400 \pm 120$ в.Р. \\
\hline $\begin{array}{l}\text { Beta-168216 } \\
\text { Sample: MHSBRAR 1-480 } \\
\text { Analysis: AMS-Standard delivery } \\
\text { Material: Charred material }\end{array}$ & 1 & 14 & 4 & $\begin{array}{l}\text { Soil-mixed ash above } \\
\text { sterile layer (early } \\
\text { habitation?) }\end{array}$ & $10,660 \pm 40$ в.Р. & $-28.80 / 00$ & $10,600 \pm 40$ в.P. \\
\hline $\begin{array}{l}\text { Beta-168217 } \\
\text { Sample: MHSBRAR2-146 } \\
\text { Analysis: AMS-Standard delivery } \\
\text { Material: Charred material }\end{array}$ & 2 & - & 4 & $\begin{array}{l}\text { Charcoal in primary } \\
\text { flexed burial collected } \\
\text { in around the left } \\
\text { humerus }\end{array}$ & $9820 \pm 50$ в.P. & $-30.80 / 00$ & $9720 \pm 50$ в.P. \\
\hline $\begin{array}{l}\text { Beta-168218 } \\
\text { Sample: MHSBRAR2-398 } \\
\text { Analysis: Radiometric-Standard } \\
\quad \text { delivery } \\
\text { Material: Charred material }\end{array}$ & 2 & 5 & 4 & $\begin{array}{l}\text { Hearth and ash mixed } \\
\text { with animal bones }\end{array}$ & $9410 \pm 80$ в.Р. & $-25.0^{*} 0 / 00$ & $9410 \pm 80$ в.P. \\
\hline $\begin{array}{l}\text { Beta-168219 } \\
\text { Sample: MHSBRAR } 2-822 \\
\text { Analysis: AMS-Standard delivery } \\
\text { Material: Charred material }\end{array}$ & 2 & - & 4 & $\begin{array}{l}\text { On West Profile, above } \\
\text { sterile layer }\end{array}$ & $10,270 \pm 50$ в.Р. & $-28.40 / 00$ & $10,210 \pm 50$ B.P. \\
\hline $\begin{array}{l}\text { Beta-168220 } \\
\text { Sample: MHSBRAR 3-850 } \\
\text { Analysis: AMS-Standard delivery } \\
\text { Material: Charred material }\end{array}$ & 3 & 17 & 3 & $\begin{array}{l}\text { Charcoal and ash feature } \\
\text { with lithic artifacts, } \\
\text { animal bone }\end{array}$ & $7300 \pm 40$ в.Р. & $-28.00 / 00$ & $7250 \pm 40$ B.P. \\
\hline $\begin{array}{l}\text { Beta-168221 } \\
\text { Sample: MHSBRAR } 31070 \\
\text { Analysis: AMS-Standard delivery } \\
\text { Material: Charred material }\end{array}$ & 3 & 22 & 5 & $\begin{array}{l}\text { Charcoal and ash feature } \\
\text { above sterile layer }\end{array}$ & $8890 \pm 50$ в.р. & $-27.70 / 00$ & $8850 \pm 50$ в.P. \\
\hline $\begin{array}{l}\text { Beta-168222 } \\
\text { Sample: MHSBRAR } 31105 \\
\text { Analysis: AMS-Standard delivery } \\
\text { Material: Charred material }\end{array}$ & 3 & 23 & 5 & $\begin{array}{l}\text { Charcoal found near } \\
\text { animal teeth in } \\
\text { habitation layer }\end{array}$ & $8270 \pm 40$ в.Р. & $-29.70 / 00$ & $8190 \pm 50$ в.P. \\
\hline
\end{tabular}




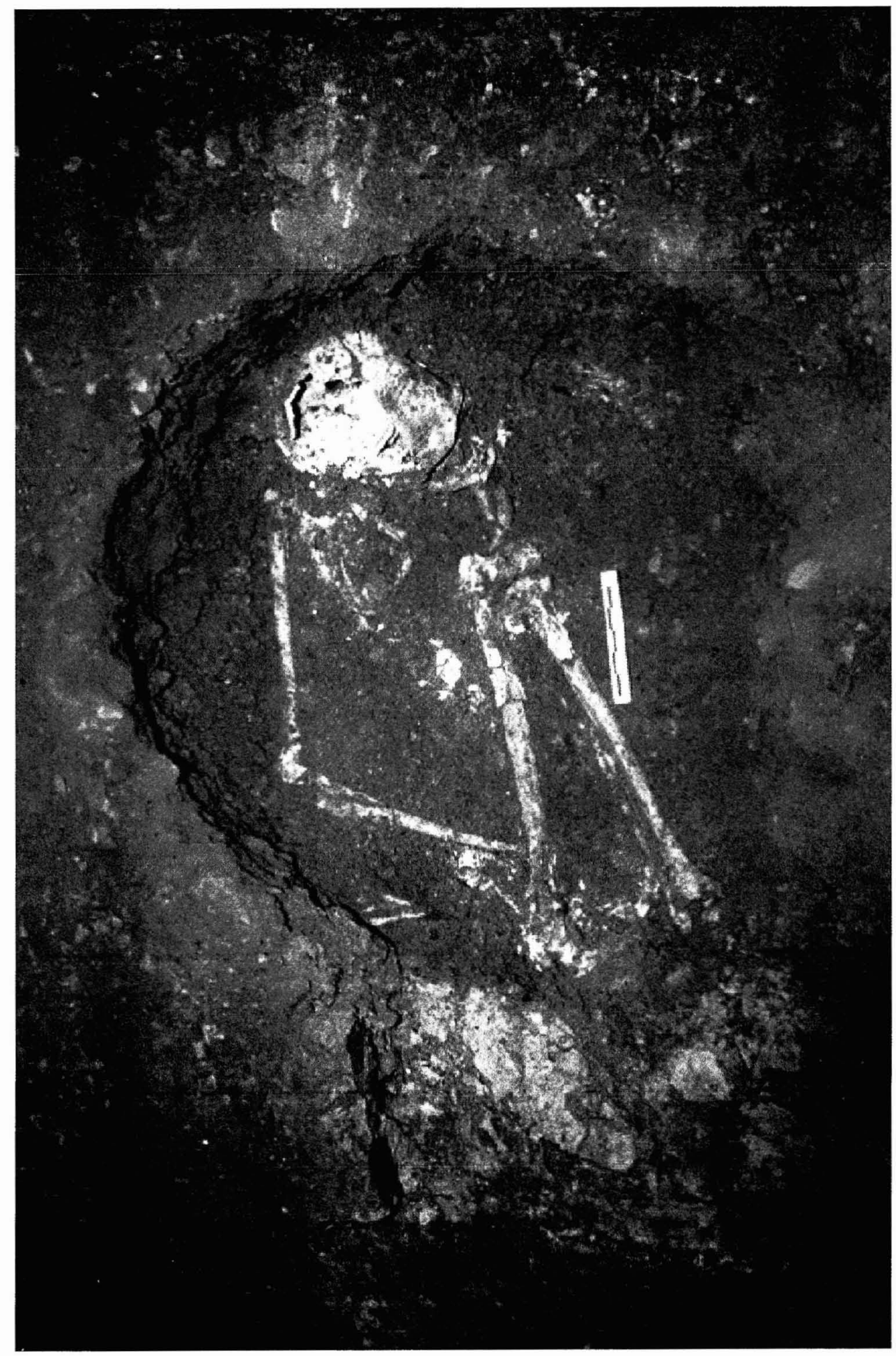

Fig. 3. Ban Rai rock shelter: primary flexed burial in Area 2. (Photograph: Cherdsak Treerayapiwat) 


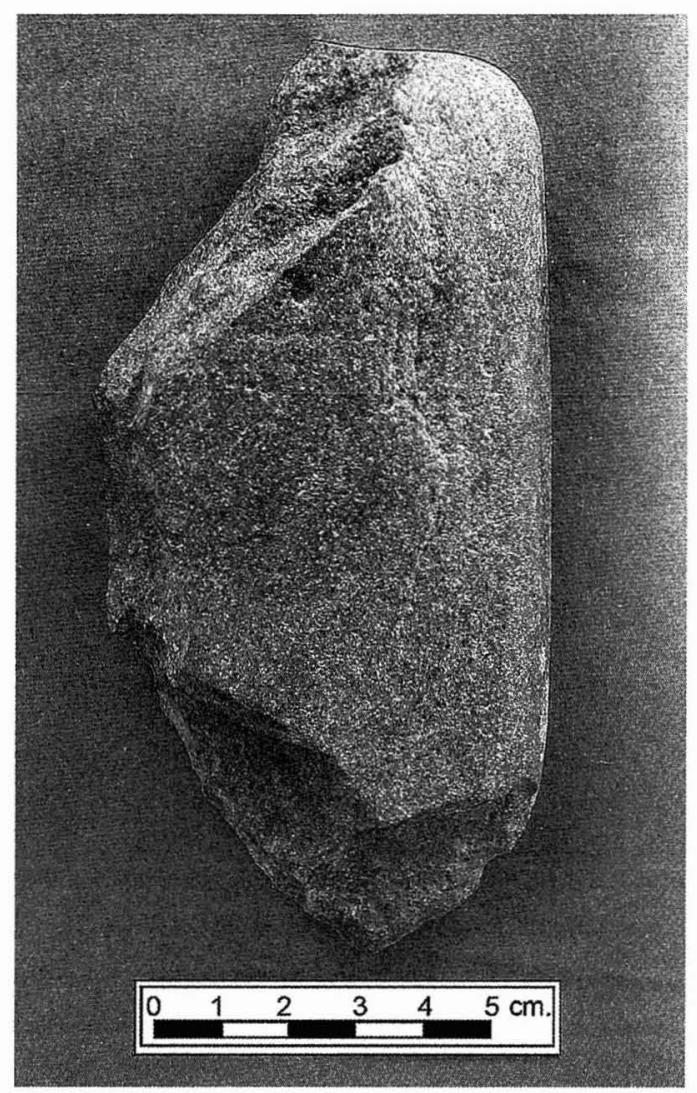

Fig. 4. A stone tool from level 12 in Area 1. (Photograph: Cherdsak Treerayapiwat)

proportion of lithic artifacts (Figs. 4 and 5) and faunal remains. Although Area 3 contained a greater density of artifacts than the other trenches, there were also many indistinguishable ash layers mixed in with the natural soil layers and continuing through the excavated levels.

The material recovered from the three excavations - the full range of lithic artifacts, abundant animal and shellfish remains, and the flexed burial-indicates that the pre-Log Coffin culture represents a stone-using period when hunting and collecting formed the basis of the subsistence pattern of the people using the site. Analogies with the flexed burial also suggest that the foraging activity at the site was contemporary with the late Pleistocene to early Holocene culture of the Malay peninsula and islands of Southeast Asia (Anderson 1990; Bellwood 1985).

\section{THE LOG COFFIN CULTURE}

Unfortunately, the excavations produced no suitable samples for dating this component, but given the high degree of similarity between the coffins at Ban Rai and those found at many other sites across Pang Mapha district, the research carried out by Grave (1995) can be used as a comparative reference from which rela- 


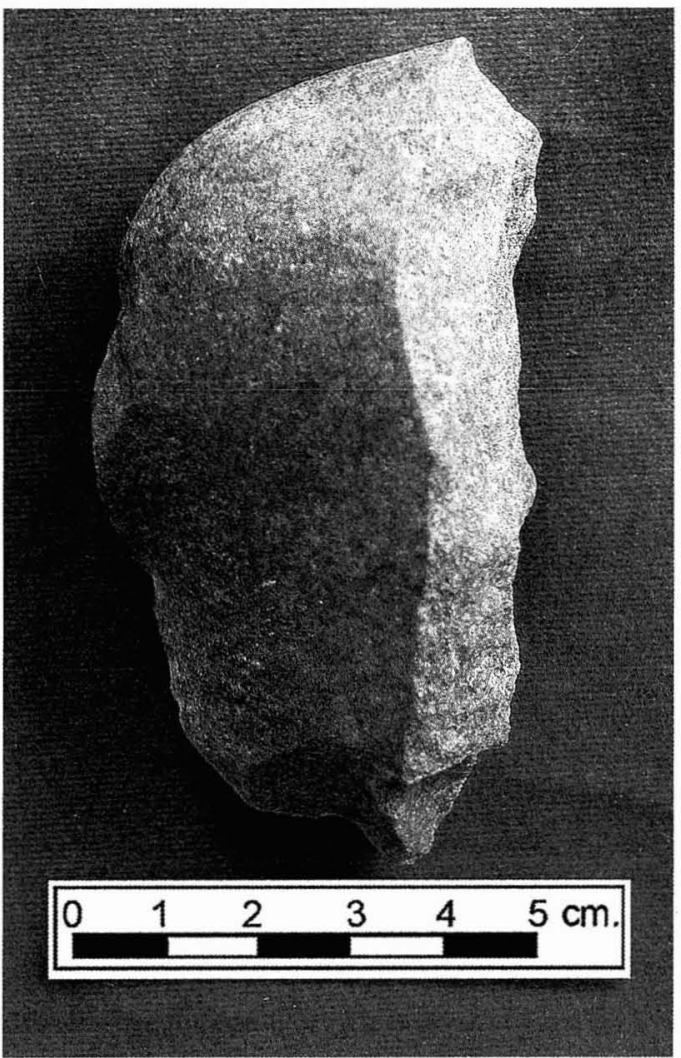

Fig. 5. A stone tool from level 17 in Area 3. (Photograph: Cherdsak Treerayapiwat)

tive dates can be assigned to the Ban Rai material. (The coffins found in Pang Mapha are often similar in general shape and form: the body consists of the carved out trunk of a tree, while at each end a rounded head was carved into the wood. Most of these coffin heads are a simple round design, although some more elaborate animal designs have been found.) Grave concluded that the coffin burials in the region can be dated generally to ca. $2100-1200$ B.P. (ca. 100 B.C.E.-C.E. 800 ), and the Ban Rai coffins can probably be assigned to this period with some confidence. Subsequent research at several Log Coffin sites across Pang Mapha has identified a number of different types or styles of coffin head (Shoocongdej 2000) that can be correlated with Grave's chronology. This research established that the samples he dated were taken from coffin head Types $1 \mathrm{~A}, 2 \mathrm{~A}, 2 \mathrm{~B}, 5 \mathrm{D}$, and $6 \mathrm{C}$, the first two (1A and 2A) being the oldest (Fig. 6). The fact that the Ban Rai coffins belong to Types $2 \mathrm{~A}, 2 \mathrm{~B}$, and $1 \mathrm{~B}$ lends support to the application of relative dating based on Grave's research to date the Log Coffin culture at Ban Rai.

Another group of archaeological evidence used to identify this component includes the wooden posts that were used for supporting the coffins. The posts in all three areas were clearly dug from the surface layer down through the deposited ash and soil layers into the pre-Log Coffin component.

However, one of the most significant features of this component is the cultural layer just below the surface of the site, within which most of the artifacts relating 


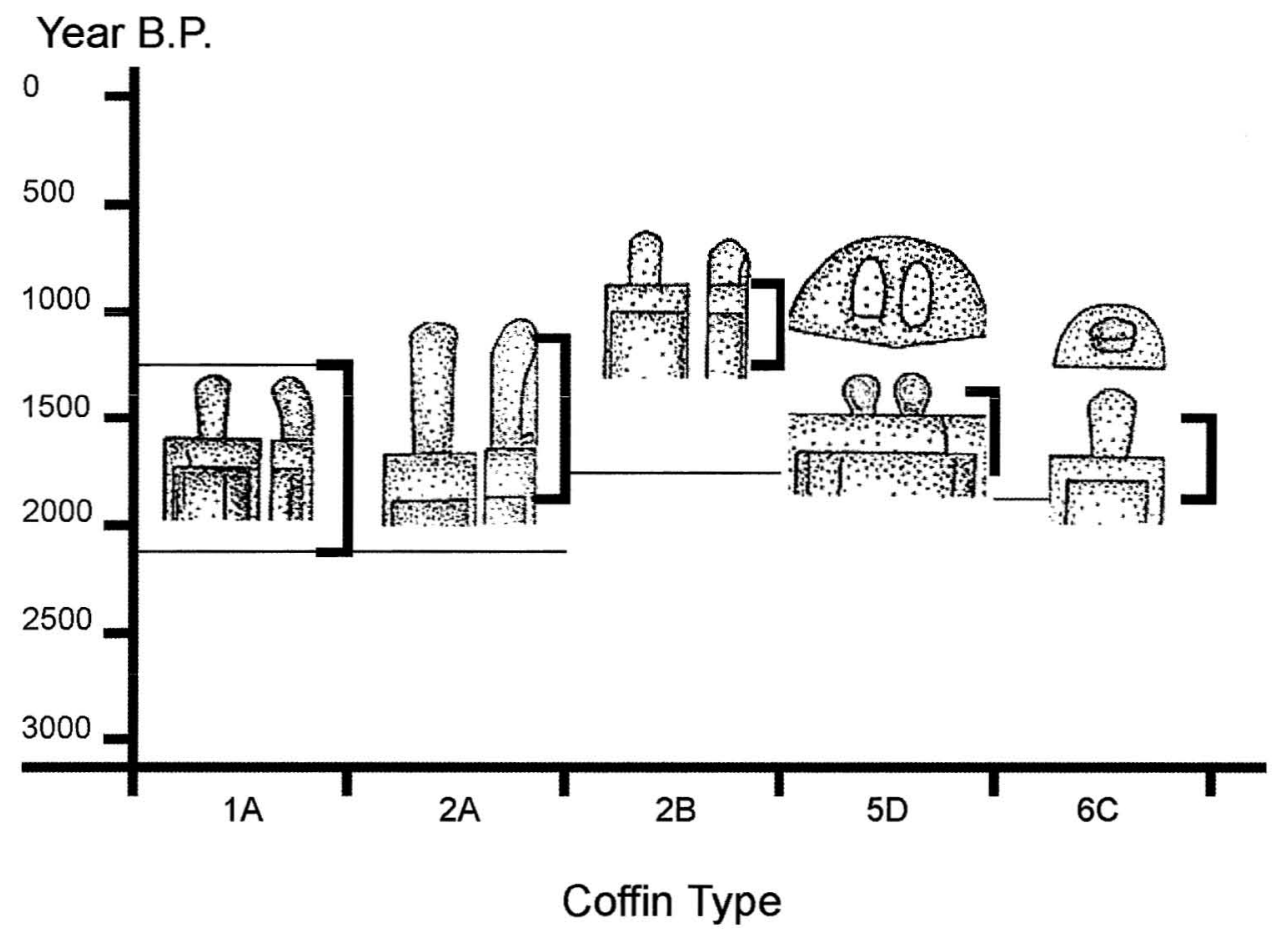

Fig. 6. The chronology of different types of coffins in the Pang Mapha district, northwestern Thailand. (After Grave 1995 and Shoocongdej 2000)

to this component were recovered. This layer, with its high proportion of mixed ash deposits, produced the greatest density of potsherds (particularly in Area 1), as well as iron tools, including one shaped like a chisel and another in the shape of a hoop. These artifacts are similar in type and design to those recovered from Log Coffin sites across the Pang Mapha region (Shoocongdej 2000).

\section{DISCUSSION}

The evidence from the Ban Rai rock shelter site contributes to our understanding of human activity and cultural change from the late Pleistocene through to the late Holocene within the district of Pang Mapha.

The pre-Log Coffin culture at the site has been dated to the late Pleistocene and early Holocene. The ${ }^{14} \mathrm{C}$ dates from the three excavated areas demonstrate continuity of use across the site, though the number of samples is not yet large enough to show absolute sequential dates. One of the most important archaeological features of this assemblage is the flexed primary burial discovered in Area 2 of early Holocene date: although it is a simple burial without associated grave goods, it does highlight another activity carried out at the site during this early phase of occupation alongside the hunting and gathering that was the primary focus of the rock shelter's use.

The period of transition between the two phases of occupation is a particularly problematic issue, because no features or artifacts were recovered to provide clear 
evidence of the cultural transition between the pre-Log Coffin and Log Coffin cultures. We would expect to recover evidence for this transitional period from the levels directly below the earliest levels within the Log Coffin cultural component, but it is clear that the Log Coffin culture itself caused major disturbance to these levels. (This explains the presence of artifacts associated with the pre-Log Coffin component, such as lithic tools, appearing within the levels ascribed to the later component.)

During the preliminary survey of Ban Rai, a large and diverse assemblage of lithic artifacts was recorded on the surface, especially on the eastern side of the site. This spatial difference is mainly due to the large number of rocks on the western side of the site that have fallen from the roof or cliff edge, making this area unsuitable or simply unattractive for habitation purposes. At the same time, the continuity between the dates assigned to the earliest cultural levels identified in Area 3 and the latest dates retrieved from Areas 1 and 2 may be evidence for a spatial movement across the site, with the main habitation area shifting from the center of the site to the eastern side. There is also evidence for the spatial use of the landscape in the Log Coffin period. The largest coffins at Ban Rai, Type 2A, on average measuring ca. 4-5 $\mathrm{m}$ in length, appear to be distributed evenly across the site, but also are usually found near the most prominent locations around the base of the rock shelter. The other types of coffins found at Ban Rai, Types $2 \mathrm{~B}$ and $1 \mathrm{~B}$, are generally smaller in length and are usually located between the larger Type 2A coffins and the wall of the shelter. Assuming the accuracy of the relative dates assigned to these coffin types (Shoocongdej 2000), which would indicate that the Type 2A coffins are the oldest coffins at Ban Rai, it is possible to conclude that the larger coffins were the first to be placed at the site and as such were located in the most desirable positions. Subsequent coffin burials then had to be located in the less prominent positions closer to the rock wall. Further analysis of the data from the Log Coffin component should help to test this hypothesis.

\section{CONCLUSION}

The research carried out by the Highland Archaeology Project at the Ban Rai rock shelter has produced a range of evidence relating to the prehistory of Pang Mapha district. The analyses of the archaeological data, in conjunction with the dating techniques applied, have allowed the identification of two separate cultural components resulting from the different human uses of this site in the past. The first, and earliest, component has been termed the pre-Log Coffin culture. The evidence contained within this component strongly indicates the presence of a lithic-using culture based around hunting and gathering in the surrounding environment. The radiocarbon dates assigned to this component of ca. 12,500 B.P. and 8000 B.P., taken from charcoal samples extracted during the excavation, place this phase of human activity from the late Pleistocene to the early Holocene periods. The second component, identified as the Log Coffin culture, consists primarily of the evidence from the log coffins and their posts, as well as the abundance of potsherds and the presence of iron tools. Relative dating applied to this component places this phase of human activity within the late Holocene, between ca. 100 B.C.E. and C.E. 800 (ca. 2100-1200 B.P.). Thus Ban Rai was first used primarily as 
a habitation site, but also as an occasional burial site, but the primary human use of the site then changed, the rock shelter being used exclusively for burial during the later phase of human activity.

\section{ACKNOWLEDGMENTS}

The Highland Archaeology Project is directed by Dr. Rasmi Shoocongdej (Department of Archaeology, Silpakorn University, Bangkok), sponsored by the Thailand Research Foundation (TRF), and supported by Silpakorn University, Chiang Mai University, Mahidol University, the Fine Art Department, and the Forestry Department of Thailand. I would like to thank Rasmi Shoocongdej for her comments and advice; Chawalit Khaokhiew and Edward Richardson for translating, proofreading, and editing the English version of this paper; and Veerasak Khlewkamput, Dejphiroon Siraboot, Natthamon Poorepatpong, Udomluk Hoontrakul, Siriluk Kantasri, Pipat Krajaechan, and everybody involved with the Highland Archaeology Project for their help and support. I would also like to thank Graeme Barker for his invitation to contribute to the Taipei symposium, and to the Indo-Pacific Prehistory Association (IPPA) for help with the expenses of attending the IPPA conference.

\section{NOTE}

1. Ban Huai Rai translates as "the garden village" and is the modern name for the village of Ban Hai, which has the same meaning but is cartographically displayed as a phonetic transcription of the local dialect.

\section{REFERENCES CITED}

Cheng, T. K.

1969 Archaeology in Sarawak. Cambridge: University of Toronto Press.

Fine Arts Department

1987 The Survey Report of Mae Hong Son Province. Unpublished report. Department of Fine Art, Bangkok. (In Thai.)

Gorman, Chester F.

1970 Excavations at Spirit Cave, north Thailand: Some interim interpretations. Asian Perspectives 13:79-107.

1971 The Hoabinhian and after: Subsistence patterns during the late Pleistocene and early recent period. World Archaeology 2:300-320.

Grave, Peter

1995 The Shift to Commodity: A Study of Ceramic Producing and Upland-Lowland Interaction in Northwestern Thailand. Ph.D. diss. University of Sydney, Sydney, Australia.

Harrisson, TOM, and Barbara Harrisson

1971 The Prehistory of Sabah. Kota Kinabalu (Sabah): Sabah Society.

Higham, Charles

1977 Economic change in prehistoric Thailand, in Origins of Agriculture: 385-412, ed. C. A Reed. Hague: Mouton.

Hoontrakul U., S. Kantasri, V. Khlaeawkamput, E. Richardson, and D. Asawamas

2002 The Cord-Marked Pottery from Log Coffin Cave Site in Highland Pang Mapha District, Mae Hong Son Province. Paper presented to the 17th Conference of the Indo-Pacific Prehistoric Association, Taipei, 9-15 September 2003.

Krajaechan, Pipad

2001 The Tree Ring Study of Log Coffin Cave: Case Study in Ban Rai Rock Shelter, Pang Mapha District, Mae Hong Son Province. B.A. thesis. Silpakorn University, Bangkok. (In Thai.) 
SAwATSAlEe, S.

1998 Rock Art Painting in Pang Mapha district, Mae Hong Son Province. B.A. thesis. Silpakorn University, Bangkok. (In Thai.)

SHOOCONGDEJ, RASMi, ED.

2000 The Final Report of Survey and Database of Caves in Pang Mapha district, Mae Hong Son Province. Unpublished report presented to the Thailand Research Foundation. (In Thai.)

2001 Progress Report 1. Unpublished report presented to the Thailand Research Foundation. (In Thai.)

$2002 a$ Progress Report 2. Unpublished report presented to the Thailand Research Foundation. (In Thai.)

$2002 b$ Progress Report 3. Unpublished report presented to the Thailand Research Foundation. (In Thai.)

Tenazas, R.C.F.

1983 The boat-coffin burial complex in the Philippines and its relation to similar practices in Southeast Asia. Southeast Asian Ministers of Education Organization Project in Archaeology and Fine Arts Coordinating Unit Digest 4(1): 11-18.

Treerayapiwat, Cherdsak

1998 The Location Study of Log Coffin Cave in Pang Mapha district,, Mae Hong Son Province. B.A. thesis. Silpakorn University, Bangkok. (In Thai.)

\begin{abstract}
The excavation of Ban Rai rock shelter (Pang Mapha district, Mae Hong Son Province, northwestern Thailand) has uncovered evidence relating to changing patterns of prehistoric human activity. Analyses of the excavation data, along with radiocarbon dating, have enabled the identification of two separate cultural components. The earlier component, the pre-Log Coffin culture, is dated by ${ }^{14} \mathrm{C}$ to between ca. 12,500 and 8000 B.P. and is characterized by a wide range of lithics, an abundance of faunal remains, and a primary flexed burial. The second component, the Log Coffin culture, probably dates to ca. $2100-1200$ B.P. and yielded human remains, potsherds, and iron tools, in addition to the log coffins themselves and their supporting posts. The composition of the artifact assemblages provided the main basis for the separation of the components, which has highlighted the changing use of the Ban Rai rock shelter from a primarily habitation to an exclusively burial site. KeYwords: Ban Rai, Log Coffin culture, lithics, Hoabinhian, flexed burial.
\end{abstract}

